\title{
Original article (Orijinal araştırma) \\ Insecticidal efficacy of local diatomaceous earths against adult and larvae of Tenebrio molitor L., 1758 (Coleoptera: Tenebrionidae) ${ }^{1}$
}

\author{
Yerli diyatom topraklarının Tenebrio molitor L., 1758 (Coleoptera: Tenebrionidae)'ün \\ ergin ve larvalarına karşı insektisidal etkinliği
}

\section{Mustafa ALKAN ${ }^{*}$}

\section{Sait ERTÜRK ${ }^{2}$}

\author{
Turgut ATAY ${ }^{3}$
}

\section{Ayşegül ÇAĞLAYAN ${ }^{3}$}

\begin{abstract}
In this study, insecticidal activity of diatomaceous earths (DE) of different particle size (Turco 000, 004 and 020) obtained from domestic sources in Turkey were tested against Tenebrio molitor L., 1758 (Coleoptera: Tenebrionidae) larvae and adults under laboratory conditions. DE were tested against larvae and adults of $T$. molitor at four different rates $\left(0,0.001,0.002,0.003\right.$ and $\left.0.004 \mathrm{mg} / \mathrm{cm}^{2}\right)$, and $\mathrm{LC}_{50}$ and $\mathrm{LC}_{90}$ values were calculated. Turco 000 grade DE with the smallest particle size had $100 \%$ efficacy at all rates against the adults at $60 \mathrm{~h}$, and after $48 \mathrm{~h}, \mathrm{LC}_{50}$ and LC 90 values were 0.006 and $0.019 \mathrm{~g} / \mathrm{cm}^{2}$, respectively. After $48 \mathrm{~h}$ treatment, the $\mathrm{LC}_{50}$ and $\mathrm{LC}_{90}$ values for Turco 004 were 0.013 and $0.022 \mathrm{~g} / \mathrm{cm}^{2}$, respectively, whereas they were 0.022 and $0.041 \mathrm{~g} / \mathrm{cm}^{2}$ with Turco 020 , respectively. The DE applied to the larvae had activity in varying proportions. $L C_{50}$ values were $0.014,0.034$ and $0.032 \mathrm{~g} / \mathrm{cm}^{2}$ after $72 \mathrm{~h}$ for Turco 000,004 and 020 , respectively. $L C_{90}$ values were $0.053,0.089$ and $0.075 \mathrm{~g} / \mathrm{cm}^{2}$, respectively. The results obtained in this study are promising for control of this pest with local DE.
\end{abstract}

Keywords: Lethal toxicity, diatomaceous earth, particle size, Tenebrio molitor

Öz

Bu çalışmada Türkiye'de yerli kaynaklardan elde edilen farkı tanecik boyutuna sahip diyatom topraklarının (Turco 000, 004 ve Turco 020) Tenebrio molitor L., 1758 (Coleoptera: Tenebrionidae) larva ve erginlerine karşı insektisidal etkinliği laboratuvar koşullarında test edilmiştir. Bu amaçla diyatom toprakları dört farklı dozda $(0.001$, $0.002,0.003$ ve $0.004 \mathrm{~g} / \mathrm{cm}^{2}$ ) zararlının larva ve erginlerine karşı denenmiş, $L_{50}$ ve $L_{90}$ değerleri hesaplanmıştır. En küçük parçacık boyutuna sahip Turco 000 kodlu diyatom toprağı zararlının erginlerine karşı 60 . saat uygulama yapılan dozlarda \%100 ölüme neden olmuş ve 48 . saat sonunda $L C_{50}$ ve $L C_{90}$ değerleri sırasıyla 0.006 ve $0.019 \mathrm{~g} / \mathrm{cm}^{2}$ olarak hesaplanmıştır. 48 saatlik uygulama süresi sonunda Turco 004 için $L_{50}$ ve $L C_{90}$ değerleri sırasıyla $0.013 \mathrm{~g} / \mathrm{cm}^{2}$, $0.022 \mathrm{~g} / \mathrm{cm}^{2}$ olarak hesaplanmıştır. Aynı zaman dilimi içerisinde Turco 020 kodlu diyatom toprağı için $\mathrm{LC}_{50}$ ve $\mathrm{LC}_{90}$ değerleri ise sırasıyla 0.022 ve $0.041 \mathrm{~g} / \mathrm{cm}^{2}$ olmuştur. Zararlının larvaları için uygulama yapılan diyatom toprakları değişen oranlarda aktiviteye sahip olmuştur. Turco 000,004 ve 020 kodlu diyatom toprakları için 72 . saat sonunda $\mathrm{LC}_{50}$ değerleri sırasıyla $0.014,0.034$ ve $0.032 \mathrm{~g} / \mathrm{cm}^{2}$ olarak hesaplanırken $\mathrm{LC}_{90}$ değerleri sırasıyla $0.053,0.089$ ve $0.075 \mathrm{~g} / \mathrm{cm}^{2}$ olarak hesaplanmıştır. Bu çalışmada elde edilen sonuçlar yerel diyatom topraklarının bu zararlının mücadelesinde kullanımı açısından ümit var sonuçlar içermektedir.

Anahtar sözcükler: Letal toksisite, yerel diatom toprağı, tanecik büyüklüğü, Tenebrio molitor

\footnotetext{
${ }^{1}$ A part of this study was presented as an oral presentation at the International Congress of Agricultural Sciences Congress (09-12 May 2018, Van, Turkey).

2 Directorate of Plant Protection Central Research Institute, 06172 Yenimahalle, Ankara, Turkey

${ }^{3}$ Tokat Gaziosmanpaşa University, Faculty of Agriculture, Department of Plant Protection, 60250, Tokat, Turkey

* Corresponding author (Sorumlu yazar) e-mail: alkan0101@gmail.com

Received (Alınış): 09.04.2019 Accepted (Kabul ediliş): 02.07.2019 


\section{Introduction}

Tenebrio molitor L., 1758 (Coleoptera: Tenebrionidae), yellow mealworm, is an important pest of durable and stored products and commodities all over the world (Vainikka et al., 2006; Sallam, 2013). Larvae are very voracious and can feed on a wide variety of postharvest products from grains to flour, tobacco and foodstuffs (Sallam, 2013). Tenebrio molitor causes losses of up to $15 \%$ of grain and flour production in worldwide (Dunkel, 1992, Flinn et al., 2003; Neethirajan et al., 2007). Tenebrio molitor adults are dark brown or black, $14-17 \mathrm{~mm}$ long and elytra have the longitudinal thin line on top. The larvae have a yellowish and segmented appearance, and are 25-30 mm long. Females deposit up to 400-500 eggs in total into the food where they feed. The larvae go through 17-18 d larvae period and then turn into pupae in the same environment and have one generation per year (Hill, 2002). Besides the active consumption of grain/food material, T. molitor deposits their sticky eggs and frass in flour, which turns the flour lumpy and smelling of mold. In addition, they cause loss of quality with dirt and cause residues.

For the control of storage pests, fumigation is the preferred chemical control method worldwide, due to its rapid penetration, ease of use and low cost. Methyl bromide ( $\mathrm{MeBr}$ ) was the most widely used fumigant. However, MeBr was banned except in quarantine and preshipment uses, under the Montreal Protocol (Protocol No: 26369, 1987) due to its ozone-depleting properties. The other important fumigant is phosphine. Widespread phosphine gas usage has led to resistant insect populations and concerns about risks to human safety associated with its application (Annis, 2016).

The residue of some insecticides applied directly to protect stored grains from insect pests may cause acute or chronic toxicity to the consumer at significant levels. Also, the development of resistance in the pests also causes practical problems, such as ineffectiveness of the active ingredient. Resistance to some important stored product pests against many effective substances used in storage, such as chlorpyrifos-methyl, etrimfos, fenitrothion, malathion, pirimiphos-methyl and the like, has been reported (Arthur, 1996). Diatomaceous earth (DE) treatment is one of the alternatives to chemical control.

Diatoms, either solitary or colonial, are microscopic photosynthesizing algae that have a siliceous skeleton, called the frustule and are found in almost every aquatic environment ranging from freshwater to marine. In fact, they are found virtually anywhere there is enough moisture. They have both benthic and planktonic forms that are both are restricted to the photic zone, since they are all strictly autotrophic (water depths down to about $200 \mathrm{~m}$ depending on the water clarity). Diatoms have a variety of different diameter or length such as 20-200 microns, some even reach up to $2 \mathrm{~mm}$ in length. They are recorded in geological records since the Cretaceous period. Diatoms may occur in such large amounts and be well preserved enough to form sediments composed almost entirely of diatom frustules, these are called diatomites, or if only partly of frustules, then they are called DE. In both cases, these are economic deposits that can be used in a number of applications including agriculture, filters, paints, toothpaste and many others (Finkel et al., 2009). The chemical composition of raw DE is mostly silicon, as well as aluminum, carbon, iron, magnesium, manganese, nickel, phosphorus, sodium, sulfur, zinc and other elements (Subramanyam, 1993).

In insects, the cuticle acts as an exoskeleton and provides protection and support for internal organs. The main barrier to prevent water loss from an insect is the epicuticular lipids. In insect morphology, epicuticular lipids act as a platform for the semiochemicals and also have an important role like retention of water in the body, protection from the body external corrosive and toxic substances (Howard \& Blomquist, 2005). DE absorbs the cuticular lipids and it also abrades the cuticles of insects, and causing death by desiccation (Ebeling, 1971; Rigaux et al., 2001). DE can be successfully incorporated into the IPM programs as they have proven to be very effective against insect pest species with low mammalian toxicity, long-lasting efficacy and are natural insecticides. 
In this study, the aim was to determine the efficacy of local DE obtained from central Anatolia around Ankara Province as protectants against $T$. molitor, which is an important pest of stored products all over the world. Also, the present study was designed to assess the effect of particle size and behavioral effects of the $\mathrm{DE}$ on the insects under laboratory conditions.

\section{Materials and Methods}

\section{Insect rearing}

Tenebrio molitor was reared in $25 \times 16 \times 11 \mathrm{~cm}$ storage containers in laboratory conditions $\left(25 \pm 2^{\circ} \mathrm{C}\right.$ and $60-70 \% \mathrm{RH})$. The rearing diet consisted of a mixture of $0.5 \%$ flour and $95 \%$ wheat bran placed into production container up to two-thirds of the volume, and the top of the container was covered with tulle for ventilation. Egg cartons were placed in the container for egg deposition by the females and water-soaked cotton was placed to meet their water requirements.

\section{Bioassays}

Local Turco 000, 004 and 020 DEs were used at four different rates $(0.001,0.002,0.003$ and 0.004 $\mathrm{g} / \mathrm{cm}^{2}$ ) and untreated control placed into $16 \mathrm{~cm}^{2}$ glass bottles (Hosseini et al., 2014). Five T. molitor adults with 7-d-old or five $T$. molitor larvae with 45-50-d-old were placed in each glass bottle containing $0.11 \mathrm{~g}$ bran as the food and the mouth covered with tulle. The bottles were incubated at $25 \pm 2^{\circ} \mathrm{C}$ and $60-70 \% \mathrm{RH}$. After $12,24,36,48,60$ and $72 \mathrm{~h}$, counts were made and live and dead adults or larvae were recorded. Trials were set up to randomized block design with 18 replicates. The trials were conducted under laboratory conditions in 2018.

\section{Diatomaceous earth}

DE used in this study were acquired from a local company operating in Ankara-Kazan and Beypazarı Districts (Beg-Tuğ Mineral Corp., Turkey). The particle sizes of the DE ranged from 1-10, 10-30 and 43-65 $\mu \mathrm{m}$ for Turco 000, 004 and 020, respectively. Local DE mainly composes of $\mathrm{SiO}_{2}$ in the range of 83 to $95 \%$ and other minerals are present in oxidized forms of aluminum, calcium and iron in small amounts.

\section{Statistical analysis}

Rate-response test results were analyzed with the help of Polo-PC probit package program (LeOra, 2002) and $\mathrm{LC}_{50}$ and $\mathrm{LC}_{90}$ values and their confidence intervals were determined. All percentage mortality data were subjected to arcsine transformation $\left[n^{\prime}=\operatorname{arcsine}(\sqrt{ } n)\right]$ to obtain normal distribution, and then treated by GLM (general linear model) ANOVA procedures using package program of MINITAB 16 (Mckenzie \& Goldman, 2005) to determine the interaction between the factors and it was determined in this way whether there was any interaction.

\section{Results and Discussion}

It was determined that DEs with different particle size have different insecticidal activity against $T$. molitor adults (Table 1). Turco 000, 004 and 020 DEs did not result in any mortality of the adults after $12 \mathrm{~h}$ exposure and therefore, $\mathrm{LC}_{50}$ and $\mathrm{LC}_{90}$ values could not be calculated. After $24 \mathrm{~h}$ exposure, $\mathrm{LC}_{50}$ and LC 90 values for Turco 000 DE were 0.049 and $0.099 \mathrm{~g} / \mathrm{cm}^{2}$, respectively. As expected, the LC 50 and LC90 values decreased with increasing exposure time and after $36 \mathrm{~h}$ exposure, these values were determined as 0.017 and $0.040 \mathrm{~g} / \mathrm{cm}^{2}$, respectively. For Turco 004, LC 50 values for $24,36,48$ and $72 \mathrm{~h}$ were $0.054,0.021,0.013$ and $0.008 \mathrm{~g} / \mathrm{cm}^{2}$, respectively, and LC90 values were $0.132,0.036,0.022$ and $0.017 \mathrm{~g} / \mathrm{cm}^{2}$, respectively. $\mathrm{LC}_{50}$ and $\mathrm{LC}_{90}$ values for Turco 000 and 004 could not be calculated for $12 \mathrm{~h}$ DE exposure since no mortality was observed in any of the DE treatments, and also no probit estimations were provided in 60 and $72 \mathrm{~h}$ for 
Turco 000 and $72 \mathrm{~h}$ for Turco 004 due to $100 \%$ mortality in all application rates. LC $_{50}$ values for $24,36,48$, 60 and $72 \mathrm{~h}$ exposure for Turco $020 \mathrm{DE}$ were $0.071,0.034,0.022,0.012$ and $0.010 \mathrm{~g} / \mathrm{cm}^{2}$, respectively, and the LC90 values were $0.121,0.064,0.041,0.026$ and $0.020 \mathrm{~g} / \mathrm{cm}^{2}$, respectively. LC 50 and LC 90 values after $12 \mathrm{~h}$ DE exposure could not be calculated because there was no mortality at any DE rate.

Table 1. Insecticidal activity of local diatomaceous earth (DE) against Tenebrio molitor adults

\begin{tabular}{|c|c|c|c|c|c|c|c|}
\hline $\mathrm{DE}$ & HAT & Slope $\pm S E$ & $\begin{array}{l}\mathrm{LC}_{50} \\
\left(\mathrm{~g} / \mathrm{cm}^{2}\right)\end{array}$ & $\begin{array}{c}99 \% \\
\text { confidence } \\
\text { interval }\end{array}$ & $\begin{array}{c}\mathrm{LC}_{90} \\
\left(\mathrm{~g} / \mathrm{cm}^{2}\right)\end{array}$ & $\begin{array}{c}99 \% \\
\text { confidence } \\
\text { interval }\end{array}$ & Heterogeneity \\
\hline \multirow{6}{*}{ Turco 000} & 12 & * & * & * & * & * & * \\
\hline & 24 & $4.23 \pm 0.46$ & 0.049 & $0.045-0.055$ & 0.099 & $0.083-0.130$ & 1.14 \\
\hline & 36 & $3.38 \pm 0.41$ & 0.017 & $0.014-0.019$ & 0.040 & $0.035-0.047$ & 0.87 \\
\hline & 48 & $2.63 \pm 0.66$ & 0.006 & $0.002-0.010$ & 0.019 & $0.013-0.023$ & 0.82 \\
\hline & 60 & $* *$ & $* *$ & ** & $* *$ & $* *$ & $* *$ \\
\hline & 72 & ** & ** & $* *$ & $* *$ & ** & $* *$ \\
\hline \multirow{6}{*}{ Turco 004} & 12 & * & * & * & * & * & * \\
\hline & 24 & $3.31 \pm 0.42$ & 0.054 & $0.049-0.062$ & 0.132 & $0.104-0.195$ & 0.61 \\
\hline & 36 & $5.32 \pm 0.52$ & 0.021 & $0.019-0.023$ & 0.036 & $0.033-0.041$ & 0.82 \\
\hline & 48 & $6.16 \pm 1.27$ & 0.013 & $0.011-0.015$ & 0.022 & $0.020-0.026$ & 0.53 \\
\hline & 60 & $4.05 \pm 1.20$ & 0.008 & $0.003-0.011$ & 0.017 & $0.013-0.021$ & 0.53 \\
\hline & 72 & $* *$ & $* *$ & ** & $* *$ & ** & $* *$ \\
\hline \multirow{6}{*}{ Turco 020} & 12 & * & * & * & * & * & * \\
\hline & 24 & $5.44 \pm 0.91$ & 0.071 & $0.064-0.084$ & 0.121 & $0.098-0.185$ & 0.61 \\
\hline & 36 & $4.67 \pm 0.42$ & 0.034 & $0.031-0.037$ & 0.064 & $0.057-0.075$ & 1.07 \\
\hline & 48 & $4.76 \pm 0.44$ & 0.022 & $0.020-0.024$ & 0.041 & $0.037-0.046$ & 1.01 \\
\hline & 60 & $3.72 \pm 0.58$ & 0.012 & $0.009-0.014$ & 0.026 & $0.023-0.031$ & 0.67 \\
\hline & 72 & $4.04 \pm 0.93$ & 0.010 & $0.005-0.012$ & 0.020 & $0.017-0.024$ & 0.63 \\
\hline
\end{tabular}

HAT: hours after treatment;

* LC values could not be calculated because there was no mortality;

** LC values could not be calculated because there was $100 \%$ mortality.

Similarly, to $T$. molitor adults, the insecticidal efficacy of local DE larvae varied with particle size and exposure time (Table 2). LC 50 values for Turco 000 DE were $0.314,0.053,0.031,0.021,0.017$ and 0.014 $\mathrm{g} / \mathrm{cm}^{2}$ for $12,24,36,48,60$ and $72 \mathrm{~h}$ exposure, respectively. The LC 90 values were $1.853,0.152,0.076$, $0.067,0.059$ and $0.053 \mathrm{~g} / \mathrm{cm}^{2}$, respectively. $L_{50}$ and $L_{90}$ values could not be calculated since Turco 004 DE had no insecticidal activity at any application rates after $12 \mathrm{~h}$ exposure. $\mathrm{LC}_{50}$ values between 24 and $72 \mathrm{~h}$ exposure were $0.095,0.058,0.048,0.039$ and $0.034 \mathrm{~g} / \mathrm{cm}^{2}$. The LC 90 values were $0.242,0.139,0.112$, 0.095 and $0.089 \mathrm{~g} / \mathrm{cm}^{2}$, respectively. While the $L_{50}$ values between 24 and $72 \mathrm{~h}$ exposure for the Turco 020 DE were $0.094,0.058,0.043,0.035$ and $0.032 \mathrm{~g} / \mathrm{cm}^{2}$, respectively, The LC 90 values were $0.276,0.177$, $0.106,0.087$ and $0.075 \mathrm{~g} / \mathrm{cm}^{2}$, respectively.

DE was found to be significant in terms of time and rate interactions in statistical analysis. Both these treatments and DE by time, DE by rate and DE by time by rate interactions were statistically significant. However, DE by time by rate interactions were statistically insignificant for larvae (Table 3 ). 
Table 2. Insecticidal activity of local diatomaceous earth (DE) against Tenebrio molitor larvae

\begin{tabular}{|c|c|c|c|c|c|c|c|}
\hline DE & HAT & Slope $\pm S E$ & $\begin{array}{c}\mathrm{LC}_{50} \\
\left(\mathrm{~g} / \mathrm{cm}^{2}\right)\end{array}$ & $\begin{array}{c}99 \% \\
\text { confidence } \\
\text { interval }\end{array}$ & $\begin{array}{c}\mathrm{LC}_{90} \\
\left(\mathrm{~g} / \mathrm{cm}^{2}\right)\end{array}$ & $\begin{array}{c}99 \% \\
\text { confidence } \\
\text { interval }\end{array}$ & $\begin{array}{c}\text { Heterogeneit } \\
y\end{array}$ \\
\hline \multirow{6}{*}{ Turco 000} & 12 & $1.66 \pm 0.58$ & 0.314 & $0.138-0.448$ & 1.853 & $0.403-2.145$ & 0.75 \\
\hline & 24 & $2.80 \pm 0.37$ & 0.053 & $0.046-0.063$ & 0.152 & $0.112-0.254$ & 0.72 \\
\hline & 36 & $3.30 \pm 0.36$ & 0.031 & $0.028-0.035$ & 0.076 & $0.064-0.098$ & 1.01 \\
\hline & 48 & $2.52 \pm 0.35$ & 0.021 & $0.016-0.024$ & 0.067 & $0.055-0.092$ & 0.91 \\
\hline & 60 & $2.35 \pm 0.37$ & 0.017 & $0.011-0.021$ & 0.059 & $0.048-0.084$ & 1.09 \\
\hline & 72 & $2.16 \pm 0.38$ & 0.014 & $0.008-0.018$ & 0.053 & $0.043-0.076$ & 1.03 \\
\hline \multirow{6}{*}{ Turco 004} & 12 & * & * & * & * & * & * \\
\hline & 24 & $3.16 \pm 0.59$ & 0.095 & $0.073-0.180$ & 0.242 & $0.142-0.987$ & 1.53 \\
\hline & 36 & $3.41 \pm 0.45$ & 0.058 & $0.051-0.070$ & 0.139 & $0.105-0.226$ & 1.22 \\
\hline & 48 & $3.45 \pm 0.40$ & 0.048 & $0.043-0.054$ & 0.112 & $0.089-0.163$ & 1.27 \\
\hline & 60 & $3.36 \pm 0.37$ & 0.039 & $0.035-0.044$ & 0.095 & $0.077-0.133$ & 1.38 \\
\hline & 72 & $3.01 \pm 0.34$ & 0.034 & $0.030-0.038$ & 0.089 & $0.073-0.122$ & 1.09 \\
\hline \multirow{6}{*}{ Turco 020} & 12 & * & * & * & * & * & * \\
\hline & 24 & $2.74 \pm 0.51$ & 0.094 & $0.074-0.154$ & 0.276 & $0.164-0.878$ & 1.09 \\
\hline & 36 & $2.66 \pm 0.38$ & 0.058 & $0.051-0.071$ & 0.177 & $0.126-0.319$ & 0.94 \\
\hline & 48 & $3.24 \pm 0.37$ & 0.043 & $0.038-0.048$ & 0.106 & $0.086-0.147$ & 1.05 \\
\hline & 60 & $3.23 \pm 0.35$ & 0.035 & $0.031-0.039$ & 0.087 & $0.072-0.114$ & 1.07 \\
\hline & 72 & $3.45 \pm 0.35$ & 0.032 & $0.028-0.035$ & 0.075 & $0.064-0.093$ & 1.02 \\
\hline
\end{tabular}

HAT: hours after treatment;

* LC values could not be calculated because there was no mortality.

Table 3. ANOVA parameters for main effects and interactions for mortality of Tenebrio molitor larvae and adults

\begin{tabular}{|c|c|c|c|c|c|c|c|c|c|c|c|c|}
\hline \multirow{2}{*}{ Source } & \multicolumn{6}{|c|}{ Adult } & \multicolumn{6}{|c|}{ Larvae } \\
\hline & DF & Seq SS & Adj SS & Adj MS & $\mathrm{F}$ & $\mathrm{P}$ & DF & Seq SS & Adj SS & Adj & $\mathrm{F}$ & $\mathrm{P}$ \\
\hline DE & 2 & 37073 & 37073 & 18536 & 198 & 0 & 2 & 76136 & 76136 & 38068 & 112 & 0 \\
\hline Rate & 3 & 140923 & 140923 & 46974 & 501 & 0 & 3 & 268642 & 268642 & 89547 & 263 & 0 \\
\hline Time & 5 & 1380885 & 1380885 & 276177 & 2950 & 0 & 5 & 399273 & 399273 & 79855 & 235 & 0 \\
\hline DE by rate & 6 & 13784 & 13784 & 2297 & 24.5 & 0 & 6 & 10438 & 10438 & 1740 & 5.11 & 0 \\
\hline DE by time & 10 & 17553 & 17553 & 1755 & 18.7 & 0 & 10 & 15539 & 15539 & 1554 & 4.57 & 0 \\
\hline Rate by time & 15 & 89026 & 89026 & 5935 & 63.3 & 0 & 15 & 57462 & 57462 & 3831 & 11.3 & 0 \\
\hline DE by rate by & 30 & 19754 & 19754 & 658 & 7.03 & 0 & 30 & 9940 & 9940 & 331 & 0.97 & 0.51 \\
\hline Error & 12 & 114717 & 114717 & 94 & & & 1368 & 465610 & 465610 & 340 & & \\
\hline Total & 12 & 1813715 & & & & & 1439 & 1303041 & & & & \\
\hline
\end{tabular}


DEs with different particle size have been observed to have varying efficacy against T. molitor larvae. According to the results obtained from this study, the insecticidal activity of Turco 000 grade DE with the smallest particle size was higher than that of the other DE grades. In a previous study with the DE product Fossil Shield ${ }^{\circledR}$ with a particle size of 5-30 $\mu \mathrm{m}$ applied to plywood plates at 0,2 and $4 \mathrm{~g} / \mathrm{m}^{2}$, significant activity was reported against Tribolium confusum du Val., 1863, T. molitor, Sitophilus granarius (L., 1758) and Plodia interpunctella (Hübner, 1813) (Mewis \& Ulrichs, 2001). In present study, LC 90 value after 72 h DE exposure for Turco 000 with the smallest particle size was $0.053 \mathrm{~g} / \mathrm{cm}^{2}$. The particle size of the Fossil Shield ${ }^{\circledR}$ used in the study varies between 5-30 $\mu \mathrm{m}$, while the local DE with the smallest particle size used in this study is between $1-10 \mu \mathrm{m}$. It is also known that the chemical composition of the DE has as important role in its insecticidal activity as particle size (Korunic et al., 1998). Japp (2008) revealed that, the DE samples collected from different regions of Argentina at $63 \mathrm{~g} / \mathrm{m}^{2}$ showed the mortality for the lesser mealworm (Alphitobius diaperinus Panzer, 1797 [Coleoptera: Tenebrionidae] between 7-98\%. Oliveira et al., (2017), reported that for the elimination of the A. diaperinus from the poultry house with $280 \mathrm{~g} / \mathrm{m}^{2} \mathrm{DE}$. It has been suggested that the differences between these studies are due to particle size and chemical composition of the DEs. DEs with small particle size can be more effective than DEs with large particles. This is especially important in active moving insects. Depending on the intensity of movement and activity of the insects, the lethal effect of DEs increases. Many studies have been conducted on the use of DEs against stored product pests (Vayias et al., 2006; Vayias \& Stephou, 2009; Eroglu et al., 2019), vegetable pests (Llewellyn \& Eivaz, 1979; Ulrichs et al., 2001; El-Wakeil \& Saleh, 2009; Wakil et al., 2012) and many other pests affecting public health (Faulde et al., 2006; Hosseini et al., 2014). The number of studies on the use of environmentally-friendly inputs that have the potential to replace synthetic pesticides have increased recently. There are many studies on the use of DEs alone, or in combination with different materials to control insect pests. Combining DEs with entomopathogen fungi, plant-based essential oils and extracts are the major topics being studied (Athanassiou et al., 2006; Yang et al., 2010; Riasat et al., 2011; Wakil et al., 2011; Ashraf et al., 2017).

DE, by physically abrading cuticular layer, damages to epicuticular lipids and causes desiccation that leads to death of the insect (Ebeling, 1971; Korunic, 1998; Rigaux et al., 2001). Insect susceptibility to DEs depends on their morphology and physiology (Korunic, 1998). One of the factors of efficacy of DE in insects is the thickness of the epicuticular lipid layer. Increased thickness of this layer is considered to reduce the efficacy of DE because of reduced water loss. Mewis \& Ulrichs (2001) reported that weight loss and death did not occur in T. molitor larvae after they were treated with Fossil Shield ${ }^{\circledR}$, a commercially available DE, since DE did not cause desiccation. In this study, for $72 \mathrm{~h}$ exposure to $T$. molitor larvae, the $\mathrm{LC}_{90}$ value of Turco 000 was found to be $0.053 \mathrm{~g} / \mathrm{cm}^{2}$. Otitodun et al. (2015) revealed that, the mortalities with a 14-d treatment were 69 and 98\% for Rhyzopertha dominica (F., 1792) and S. granarius adults, respectively.

In our experiments, the $\mathrm{LC}_{50}$ value after $48 \mathrm{~h}$ exposure was $0.006 \mathrm{~g} / \mathrm{cm}^{2}$ for Turco 000 with the smallest particle size. In insects, the different reactions of larvae and adult stages to DE can be explained by the natural differences occurring in cutaneous compounds between biological phases. The variation of mortality rates between species can be attributed to the origin of DEs (fresh or marine) as well as their physical and chemical properties, and environmental factors such as temperature and humidity and physiological and morphological characteristics of insects.

In conclusion, the results obtained in this study are promising for the control of $T$. molitor with local DEs. It is also considered that present study will become more significant with the help of other disciplines, which enable different formulations of DEs. That will definitely help further development of the DEs by the pesticide industry. 


\section{References}

Annis, P. C., 2016. "Chemicals for Grain Production and Protection, 99-104". In: Encyclopedia of Food Grains (Vol. 4), (Eds. C. Wrigley, H. Corke, K. Seetharaman \& J. Faubion), Elsevier, Oxford, UK, 491 pp.

Arthur, F. H., 1996. Grain protectants: current status and prospects for the future. Journal of Stored Products Research, 32 (4): 293-302.

Ashraf, M., M. Farooq, M. Shakeel, N. Din, S. Hussain, N. Saeed, Q. Shakeel \& N. A. Rajput, 2017. Influence of entomopathogenic fungus, Metarhizium anisopliae, alone and in combination with diatomaceous earth and thiamethoxam on mortality, progeny production, mycosis, and sporulation of the stored grain insect pests. Environmental Science and Pollution Research, 24 (36): 28165-28174.

Athanassiou, C. G., Z. Korunic, N. G. Kavallieratos, G. G. Peteinatos, M. C. Boukouvala \& N. H. Mikeli, 2006. "New trends in the use of diatomaceous earth against stored-grain insects, 15-18". In: Proceedings of the $9^{\text {th }}$ International Working Conference of Stored-Product Protection (15 October-18 October 2006, Sao Paulo, Brazil), $1359 \mathrm{pp}$.

Dunkel, F. V., 1992. The stored grain ecosystem: a global perspective. Journal of Stored Production Research, 28: 73-87.

Ebeling, W., 1971. Sorptive dusts for pest control. Annual Review of Entomology, 16: 123-158.

El-Wakeil, N. E. \& S. A. Saleh, 2009. Effects of neem and diatomaceous earth against Myzus persicae and associated predators in addition to indirect effects on artichoke growth and yield parameters. Archives of Phytopathology and Plant Protection, 42 (12): 1132-1143.

Eroglu, N., M. K. Sakka, M. Emekci \& C. G. Athanassiou, 2019. Effects of zeolite formulations on the mortality and progeny production of Sitophilus oryzae and Oryzaephilus surinamensis at different temperature and relative humidity levels. Journal of Stored Products Research, 81: 40-45.

Faulde, M. K., M. Tisch \& J. J. Scharninghausen, 2006. Efficacy of modified diatomaceous earth on different cockroach species (Orthoptera, Blattellidae) and silverfish (Thysanura, Lepismatidae). Journal of Pest Science, 79 (3): 155-161.

Finkel, Z. V., J. Beardall, K. J. Flynn, A. Quigg, T. A. V. Rees \& J. A. Raven, 2009. Phytoplankton in a changing world: cell size and elemental stoichiometry. Journal of Plankton Research, 32 (1): 119-137.

Flinn, P. W., D. W. Hagstrum, C. Reed \& T. W. Phillips, 2003. United States Department of Agriculture-Agricultural Research Service stored-grain area-wide integrated pest management program. Pest Managing Science, 59: 614-618.

Hill, D. S., 2002. Pests of Stored Foodstuffs and Their Control. Kluwer Academic Publishers, The Netherlands, 496 pp.

Hosseini, S. A., S. Bazrafkan, H. Vatandoost, M. R. Abaei, M. S. Ahmadi, M. Tavassoli \& M. Shayeghi, 2014. The insecticidal effect of diatomaceous earth against adults and nymphs of Blattella germanica. Asian Pacific Journal of Tropical Biomedicine, 4 (1): 228-232.

Howard, R. W. \& G. J. Blomquist, 2005. Ecological, behavioral, and biochemical aspects of insect hydrocarbons. Annual Review Entomology, 50: 371-393.

Japp, A. K., 2008. Influência do Alphitobius diaperinus (Panzer, 1797) (Coleoptera, Tenebrionidae) no desempenho zootécnico de frangos de corte e avaliação da terra de diatomácea como estratégia para o seu controle. (Unpublished) MSc. Dissertation, Universidade Federal do Paraná, Curitiba, PR, Brazil, 61 pp.

Korunic, Z., 1998. Diatomaceous earths, a group of natural insecticides. Journal of Stored Products Research, 34: 87-97.

Leora Software, 2002. Polo-Pc: Probit and Logit Analysis, Berkeley, CA, the USA.

Llewellyn, M. \& J. Eivaz, 1979. Abrasive dusts as a mechanism for aphid control. Entomologia Experimentalis et Applicata, 26 (2): 219-222.

Mckenzie, J. D. \& R. Goldman, 2005. The Student Guide to MINITAB Release 14 Manual. Pearson Education, Boston, MA.

Mewis, I. \& C. Ulrichs, 2001. Action of amorphous diatomaceous earth against different stages of the stored product pests Tribolium confusum, Tenebrio molitor, Sitophilus granarius and Plodia interpunctella. Journal of Stored Products Research, 37 (2): 153-164.

Neethirajan, S., C. Karunakaran, D. S. Jayas \& N. D. G. White, 2007. Detection techniques for stored-product insects in grain. Food Control 18: 157-162. 
Oliveira, D. G. P., A. K Bonini \& L. F. A. Alves, 2017. Field assessments to control the Lesser mealworm (Coleoptera: Tenebrionidae) using Diatomaceous earth in poultry houses. Journal of Economic Entomology, 110 (6): 2716 2723.

Otitodun, G. O., G. P. Opit, S. I. Nwaubani, E. U. Okonkwo \& S. G. Gautam, 2015. Efficacy of Nigeria derived diatomaceous earth, botanical insecticides, and river bed sand against Sitophilus oryzea (Coleoptera: Curculionide) and Rhyzopertha dominica (Coleoptera: Bostrichdea) on wheat. African Crop Science Journal, 23 (3): 279-293.

Riasat, T., W. Wakil, M. Ashfaq \& S. T. Sahi, 2011. Effect of Beauveria bassiana mixed with diatomaceous earth on mortality, mycosis and sporulation of Rhyzopertha dominica on stored wheat. Phytoparasitica, 39 (4): 325-331.

Rigaux, M., E. Haubruge \& P. G. Fields, 2001. Mechanisms for tolerance to diatomaceous earth between strains of Tribolium castaneum. Entomologia Experimentalis Applicata, 101: 33-39.

Sallam, M. N., 2013. Insect Damage: Post-harvest Operations. International Centre of Insect Physiology and Ecology, Food and Agriculture Organization of the United Nations, Rome, Italy, 38 pp.

Subramanyam, B. H., 1993. Chemical Composition of Insecto. Report of Department of Entomology, University of Minnesota, St. Paul, M.N., 4pp.

Ulrichs, C. H., I. Mewis, \& W. H. Schnitzler, 2001. Efficacy of neem and diatomaceous earth against cowpea aphids and their deleterious effect on predating Coccinelidae. Journal of Applied Entomology, 125 (9-10): 571-575.

Vainikka, A., O. Seppala, K. Loytynoja \& M. J. Rantala, 2006. Fitness consequences of female preference for male pheromones in Tenebrio molitor. Evolution Ecology Research, 8: 943-957.

Vayias, B. J., C. G. Athanassiou \& C. T. Buchelos, 2006. Evaluation of three diatomaceous earth and one natural pyrethrum formulations against pupae of Tribolium confusum du Val (Coleoptera: Tenebrionidae) on wheat and flour. Crop Protection, 25 (8): 766-772.

Vayias, B. J. \& V. K. Stephou, 2009. Factors affecting the insecticidal efficacy of an enhanced diatomaceous earth formulation against three stored-product insect species. Journal of Stored Products Research, 45 (4): $226-231$.

Wakil, W., M. U. Ghazanfar, Y. J. Kwon, E. Ullah S. Islam \& K. Ali, 2012. Testing Paecilomyces lilacinus, diatomaceous earth and Azadirachta indica alone and in combination against cotton aphid (Aphis gossypii Glover) (Insecta: Homoptera: Aphididae). African Journal of Biotechnology, 11 (4): 821-828.

Wakil, W., T. Riasat, M. U. Ghazanfar, Y. J. Kwon \& F.A. Shaheen, 2011. Aptness of Beauveria bassiana and enhanced diatomaceous earth (DEBBM) for control of Rhyzopertha dominica F. Entomological Research, 41 (6): $233-241$.

Yang, F. L., G. W. Liang, Y. J. Xu, Y. Y. Lu \& L. Zeng, 2010. Diatomaceous earth enhances the toxicity of garlic, Allium sativum, essential oil against stored-product pests. Journal of Stored Products Research, 46 (2): 118-123. 